\title{
Change of Management Accounting Practices
}

\author{
Yudhi Herliansyah $^{1}$
}

\begin{abstract}
:
Currently, the use of traditional management accounting techniques such as traditional product costing is not meeting user needs for a variety of reasons. It has been claimed that traditional management accounting techniques are unable to satisfy the users of such techniques in terms of providing them with timely and detailed information.

The use of management accounting techniques to support business processes, enabling competitive advantage and creating value is highly relevant for most businesses today. It also encourages the provision of capabilities to reduce cost and improve product quality, process flexibility, and build relationships "supplier-customer" and ultimately improve performance.

The research has been done by investigating the contribution of the ease of use and usefulness to accept a change in the hospital management accounting system. All the hospitals (37 hospitals) in Jakarta constituted our population. A sample for this research used 23 management accounting system changes.

Our research shows that hospital management accounting system changes are acceptable. The disagreement is related with the functional issues required to support the new system.

Previous researchers argue that the delegation of decision rights (decentralization) can reduce the potential for resistance of management accounting innovation implemented in two ways: (a) by creating the environment which allows managers to ensure that their subunits are able to adapt to the new signals provided by accounting innovations and (b) by enabling subunit managers to become involved in the design of these systems.
\end{abstract}

Keywords: Acceptance management accounting change, ease of use, usefulness, acceptance management accounting technic change.

${ }^{1}$ Universitas Mercubuana Jakarta, Indonesia, yudhiherliansyah@mercubuana.ac.id 


\section{Introduction}

Hospital industries has been through significant development since the derelgulation of hospital policy included in UU no. 44 in 2009. Up until 2016, the record of hospital development shows the development of 2.045 public hospitals and 556 private hospitals which is on average $7 \%$ per year. It happens because of the social security deregulation which has been put into action in accordance to laws of social insurance. It also includes health assurance for Indonesian citizens which is organized and managed by the social security administrative bodies. As a consequence, this health deregulation situation has triggered quite acute rivalry among Indonesian hospital industries which forces the hospitals to make improvements in every aspect, in order to give good quality services. It needs to be done so that they could maintain their industries on track. The Government's interest in health care encourages the hospital's management to make improvements in every aspect. Management accounting practice is one of the most important points that helps managing operators in making policy or change for the hospital itself. For decades, changes in management accounting practices have been an interesting topic of research (Suryanto and Thalassinos, 2017). Nevertheless, there is still a lack of thorough attention given to this discussion which only shows few adjustments in the implementation of accounting management systems in hospitals. This impact comes from the the fact that accounting management has lost its relevance (Kaplan, 1986).

Management accounting practice is a kind of accounting management system which consists of a collection of practices such as budgeting and product costing that is systematically used for supporting organization goal attainment (Chenhall, 2003). Accounting Management systems take a part in budgeting control and has a major responsibility of the hospital especially in its expense and activity quality (Campanale, 2012). However, some researches argue that this fails to implement innovative change in the accounting management system, yet other researches prove that this system has a postive impact towards organization performance. There is a high probability that other management accounting practices such as Activity Based Costing (ABC), Life Cycle Costing (LCC), Target Costing (TC), and Balanced Scorecard (BSC) could be able to facilitate management's final decision and increase organization performance compared to other traditional accounting management systems such as traditional costing (Kaplan, 1986; Anderson and Young, 2002).

However, a lot of reasearch has shown numerous facts against it. Innes and Mitchell, (1991), Cooper et al. (1992), Abernethy and Lillis (1995), Cavalluzzo and Ittner (2004) and Hapsoro and Suryanto (2017) state their disagreement by claiming that some organizational internal factors do not fit the accounting management technique which has been implemented either as structural, individual, technological and other internal organizational factors. Other research focuses on the organization's problem which relates to the alteration of accounting management pratices. Such emphirical reseach tested the reasons behind the effect of strategy, policy practice, and internal 
management structure toward the successfulness of accounting management system implementation and diffusion (Shields, 1997; Krumwiede, 1998). Only a small number of researches have discussed the issue on an individual level such as understating the implementer's attitude of the accounting management alteration and factors which cause it. This paper examines the acceptance of change in management accounting practices in the Jakarta province hospitals.

\section{Literature Review}

\subsection{Organizational change}

According to Broadbent and Laughlin (2005), there are four main questions in analyzing organizational change and its relation to accountancy:

(1) How organizational and accounting change correspond and interact. Various conditions are able to make clear the condition, yet the accounting change could be viewed as a part of organizational changing process.

(2) What characteritics do the organizations have? There are a lot of opinions related to this point. One of those opinions is the case in which organization exists because of accumulated history and organizations which depends solely to the most powerful stakeholders who push it to change itself.

(3) What are the identifying features and organizational processes? An organization has an orientated tendency like "inertia" which tends to prefer stable change rather tham major change.

(4) Theoritical roles in providing an understanding of organizational and accounting change in organizational context. It depends on ontological assumptions related to the opportunity to attain social justification and generalization out of the previous emphirical study.

This research aims to find an answer, especially on point 1 above which could serve as a more detailed explanation of Broadbent and Laughlin's questions (2005).

The change in organizational environment demands a fast adaption of the organization in order to survive (Jones, 2004). Environmental change in organizations is the result of pressure in which the organization itself needs to change. Nevertheless, some resistences occur alongside this change inside the organization. Kotter and Schlesinger (1979) state that there are several factors which must take into consideration for an organizational change as:

1. Competitive forces;

2. Economic, political, and global forces;

3. Demographic and social forces;

4. Ethical forces.

Still, the change made in the organization is not something simple and straightforward since rejection and resistence threaten it from happening. The 
resistance occurs because of the groups within the organization which develop strong informal norms, based on appropriate and inappropriate attitudes involved in the interaction among the groups. At times, the changes influence the roles and responsibilities of each group which results in norm infraction and violation of informal expectation toward each other. Later on, these conditions feed on the broken relationship which brings in resistence in one organization.

The resistence of organizational change begins from the individual level in one organization. Individuals resist the change because they feel uncertain and uncomfortable of their future outcome. They might receive some new jobs, new roles, or even lose their jobs which makes them tend to delay or slow the change down, or even refuse it.

\subsection{The change in management accounting practice}

Accounting management literature states that management accounting practices have transformed considerably from traditional accounting management, from variance analysis and financial based performance measurement to a more contemporary accounting management because of the developement of informational technology, comptetive environment, economic resession, and contemporary management accounting practices (Chenhall and Langfield-Smith, 1998; Waweru et al., 2004). The change towards a contemporary accounting management is used to support organizational operation in a dynamic environment which encourages many developed countries to introduce new management accounting practice and financial accounting system such as; Activity Based Costing (ABC), Activity Based Management (ABM), Target Costing, Product Life Cycle Costing, Quality Cost Management, Customer Accounting and Balanced Scorecard (BSC) to measure performance (Waweru et al., 2004; Permana, 2017; Suryanto, 2016). Some contemporary management accounting practices are explained in such a detail: Activity Based Costing (ABC) is a method of overhead official costing of products based on activities which could be searched related to the process of producting goods. $\mathrm{ABC}$ has gained lots of attention since financial management inovation that many customers recommend the use of $\mathrm{ABC}$ in order to support the increasing process and to develop a cheaper costing product design (Cooper and Turney, 1989). Despite its connection to manufacture enterprise, ABC could be implemented to all kinds of organizations.

\subsection{Acceptance of change in management accounting practice}

Management accounting information systems are used by corporations so that they could force the management in their corporation to do particular activities or works. The use of an informational system is based on the principle that it is capable of motivating the system user to comply, conform and fit to their belief on how important the informational system is. In association to this concept, many reseaches focus on how the system users are convinced and influenced to adopt and use the 
system and new technology (Lewin and Miller, 1982; Vankatesh and Davis, 2003). Corporations implement information systems that are connected to basic action choice for communicatioon, collaboration, and coordination (Cooper et al., 1992). It is expected that by implementing this concept, managerial compulsive system could be obeyed for its eficiency and worthiness (Cooper et al., 1992; Davis et al., 1989). In addition, several reseaches have found that the aim of using the system is to support the improvement of knowledge activity (self-determined knowledge activities), such as sharing, creating and improving.

The acceptance of change in a system is related to a scematic approach in which acceptance is defined as a structure to control attention and recontructions from someone's memory. It would help people to effectively simplify and manage the information around them as cognitive, interpretative guidance, and a method to understand some events or objects (Setyawati et al., 2017).

Only few studies discussed something related to innovative accounting acceptance on a managerial level. Some studies has succeed in testing out the changes of accounting management system after the implementation of ABC such as Anderson (1995) and Krumwiede (1998). Other researches have indentified some alteration that occured on the accounting system (Miller, 1980). Based on the explanation given, this study aimed to figure out how the production manager responded to the occuring changes in the accounting management system.

Significant progress has been succesfully made in the recent decades to explain and predict the user acceptance over the informational technology in work field. Substantial theory and supporting researches were accumulated in a model known as Technology Acceptance Model (TAM) (Davis et al., 1989). In TAM, the users' intention in using a system is devided into two beliefs:

$\checkmark$ Perceived usefulness is defined as how deep someone believes that a system will increase his performance (Venkatesh and Davis, 2003).

$\checkmark$ Perceived ease of use is identified as how deep someone's belief in which by using technology, the work will be effortless (Venkatesh and Davis, 2003).

These two beliefs meditate the influence of external variables to the intensity of using the system. The external variables are system characteristics, developing process, and practice. In testing the TAM implementation, a constant use of perceived usefulness is categorized as a strong determinance with standardized regression coefficient which is around 0,6 toward the system useful intensity.

\section{Research methodology}

The design used in this research focused on the exploration related to: (1) identification of 23 types of location in which the change of accounting management 
systems are being implemented in hospitals in the capital region of Jakarta; (2) identification of changing volume in accounting management being implemented in hospitals in the capital region of Jakarta; (3) types of alteration in accounting management being implemented in hospitals in the capital region of Jakarta.

\subsection{Variables and measurement}

The research variables of this study cover 23 types of 5 subsystems in the alteration of accounting management technique being implemented and analyzed by the following instruments:

1. Asking and requesting the respondences to questionnaires to give related to subsystem alteration and/or the alteration of hospital accounting management technique.

2. Asking and requesting the respondences to questionnaires to give the quantity or the location of the management accounting practice alteration happened in each subsystem during the last 3 years in the hospital.

3. Asking and requesting the respondences to questionnaires to give the volume of management accounting practice alteration done by the hospital.

4. Asking and requesting the respondences to questionnaires to give the characteristics and types of management accounting practice alteration done by the hospital.

\subsection{The definition of operational variables}

The change of the accounting management technique in this research was defined as the change which was implemented in a hospital in which the variables to be analyzed were location and volume in 23 activities below:

Subsystem 1: Planning systems

1. Budgeting

2. Operations planning (production)

3. Capital budgeting

4. Strategic planning

5. Other planning systems

Subsystem 2: Controlling systems

6. Individual or team-based performance measurement

7. Organizational performance measurement

8. Measurement of performance in terms of quality

9. Measurement of performance in terms of customer satisfaction

10. Other performance measures

Subsystem 3: Costing systems

11. Direct allocation of manufacturing overhead 
12. Direct allocation of marketing costs

13. Direct allocation of other overhead

14. Internal (dept, or divisional) product transfers

15. Other costing systems

Subsystem 4: Directing systems

16. Reward systems - bonuses

17. Reward systems - pay-for-performanee plans

18. Other reward systems

Subsystem 5: Decision-making systems

19. Information reported more frequently

20. Use of more nonfinancial measures

21. Information reported more broadly

22. Other changes to reporting systems

23. Other changes to systems that do not appear on this list.

The characteristics and types of the changes include; addition, replacemet, modification, and reduction. Data was collected by distributing questionnaires in hospitals in Jakarta and conducting interviews. In accordance with the research method chosen, exploratory research was used in which perspective analysis and numbers of techniques that explored the implementation of management accounting practice in the hospital by describing the percentage of each accounting management technique implementation and the frequency used was discussed.

\section{Results}

Indonesia is a country with a considerably high population and there is a need of good health care which must be taken into serious consideration by the government. Law UU number 44 in 2009 about hospital or health care explained that the state and local government were under the obligation to provide hospitals based on the citizens' needs. Hence, hospital could be founded by the government itself or other private corporations. However, in order to be able to build one hospital, they have to fullfill some law provisions in which they must have human resources. These included: (1) job holder or permanent employees to cover the medical unit and medical support, nurses, pharmacy and hospital management staff; (2) non-health employees, numbers of human resources have to fit the types and classification of its hospital and because of that condition, each hospital's human resources would be different in quantity. Here are some hospital's human resources sampling.

Table 1. Numbers of human resources sample

\begin{tabular}{llll}
\hline NO & Numbers of Employee & $\begin{array}{l}\text { No. } \\
\text { Hospital }\end{array}$ & Of \\
& & Percentage \\
\hline 1 & $<1.000$ & 21 & 56,76 \\
2 & $1.000-1.999$ & 8 & 21,62 \\
\hline
\end{tabular}




\begin{tabular}{llll}
\hline 3 & $2.000-2.999$ & 3 & 8,11 \\
4 & $3.000-3.999$ & 1 & 2,70 \\
5 & $4.000-5.000$ & 1 & 2,70 \\
6 & $>5.000$ & 5 & 13,52 \\
& Tot a 1 & 37 & \\
\hline
\end{tabular}

Based on Table 1, 56,76\% of hospitals who had less than 1000 employees were those of private corporations. Whereas, hospitals under government's care employed more than 5000 members of staff on the condition that suits the law provision number 44 of 2009 related to the function of a hospital where despite its' role as health or medical services, it also functioned as a place for education, practice, and research. In most cases, private hospitals did not fullfill the function of education, practice, and reasearch because of limited human resources.

The number of hospital employees who worked in big hospitals described their effort to give immediate responses for the increasing service requests. The increasing size showed that a corporation tried to respond to its surrounding because the environmental alteration, including corporate operation and facing lots of hospital indutrial rivalry. Several researches drew the opposite results where the more employees one hospital had, the higher the complexity in the organization and the lower the acceptance of change. In addition, it gives impact to a higher resistance attitude when the changes were implemented (Shield, 1997).

\subsection{Management accounting practice}

The Statement of Financial Accounting Concept No 2 states that accountancy is an informational system with the sole main goal to act as the final decision maker. The more information gained to help in making the final decision with high quality, the better one corporation will be. A capable manager has to provide relevant information fast which would be used later on for effective design and discussion aside from its original role for absorbing and solving problems and solutions. Accounting is a kind of a pervasive and significant issue that can be found in organizational informational processes. Basically, an accounting management system is the main source for accounting information (Jones, 2004). In many literature discussions, writers have taken turn in using the term management accounting practice along side management accounting system.

\subsection{The acceptance of change}

This research did an exploration by stating the nature of change out of its essential aspects the ease of use, and its benefit of use. Table 2 presents the result of aspects in the alteration or change of management accounting characteristics by paying attention to its importance and successful implementation that could be measured by low (score 1), average (score 2), and high (scale 3) scale. 
Table 2. The importance of change successfulness

\begin{tabular}{|c|c|c|c|c|c|c|c|}
\hline & \multirow{2}{*}{ System } & \multicolumn{3}{|c|}{ The importance of change } & \multicolumn{3}{|c|}{ The success of change } \\
\hline & & Low & Average & High & Low & Average & High \\
\hline \multirow[t]{2}{*}{1} & Planning & 13 & 19 & 5 & 12 & 16 & 9 \\
\hline & & $35,1 \%$ & $51,3 \%$ & $13,5 \%$ & $32,4 \%$ & $43,2 \%$ & $24,3 \%$ \\
\hline \multirow[t]{2}{*}{2} & Controlling & 10 & 21 & 6 & 8 & 21 & 8 \\
\hline & & $27,0 \%$ & $56,7 \%$ & $16,2 \%$ & $13,5 \%$ & $56,7 \%$ & $13,5 \%$ \\
\hline \multirow[t]{2}{*}{3} & Costing & 21 & 6 & 10 & 3 & 17 & 7 \\
\hline & & $56,7 \%$ & $16,2 \%$ & $27,0 \%$ & $8,1 \%$ & $45,9 \%$ & $18,9 \%$ \\
\hline \multirow[t]{2}{*}{4} & Directing & 21 & 9 & 7 & 13 & 16 & 8 \\
\hline & & $56,7 \%$ & $24,3 \%$ & $18,9 \%$ & $35,1 \%$ & $43,2 \%$ & $13,5 \%$ \\
\hline \multirow[t]{2}{*}{5} & Decision & 23 & 8 & 6 & 9 & 18 & 10 \\
\hline & Making & $62,1 \%$ & $13,5 \%$ & $15,2 \%$ & $24,3 \%$ & $48,6 \%$ & $27,0 \%$ \\
\hline
\end{tabular}

Table 2 shows the importance of management accounting change in the organization. This result describes that the changes done were still below average in every aspect. Whereas the point of change shows that the change had succeed since the implementation level had an average percentage.

Overall, Table 2 gives a detailed picture of where the change resistence still happens in the hospital industries since the level of success of management accounting change were at its lowest point, 35,1\%. Table 3 explains in more detail the success viewed from the ease of use aspect and benefit of use aspect of the management accounting change.

Table 3. Factors of change successfulness

\begin{tabular}{|c|c|c|c|c|c|c|c|}
\hline & \multirow{2}{*}{ System } & \multicolumn{3}{|c|}{ Ease of use } & \multicolumn{3}{|c|}{ usefulness } \\
\hline & & Low & Average & High & Low & Average & High \\
\hline \multirow[t]{2}{*}{1} & Planning & 15 & 18 & 4 & 12 & 18 & 7 \\
\hline & & $40,1 \%$ & $48,6 \%$ & $10,8 \%$ & $32,4 \%$ & $48,6 \%$ & $18,9 \%$ \\
\hline \multirow[t]{2}{*}{2} & Controlling & 21 & 13 & 3 & 8 & 21 & 8 \\
\hline & & $56,7 \%$ & $35,1 \%$ & $8,1 \%$ & $13,5 \%$ & $56,7 \%$ & $13,5 \%$ \\
\hline \multirow[t]{2}{*}{3} & Costing & 27 & 8 & 2 & 3 & 17 & 7 \\
\hline & & $72,9 \%$ & $13,5 \%$ & $5,4 \%$ & $8,1 \%$ & $45,9 \%$ & $18,9 \%$ \\
\hline \multirow[t]{2}{*}{4} & Directing & 21 & 13 & 3 & 11 & 16 & 10 \\
\hline & & $56,7 \%$ & $35,1 \%$ & $8,1 \%$ & $29,7 \%$ & $43,2 \%$ & $27,0 \%$ \\
\hline \multirow[t]{2}{*}{5} & Decision & 25 & 11 & 1 & 9 & 21 & 7 \\
\hline & Making & $67,5 \%$ & $29,7 \%$ & $2,7 \%$ & $24,3 \%$ & $56,7 \%$ & $18,9 \%$ \\
\hline
\end{tabular}

Table 3 above shows that the highest rate of management accounting change, $72,2 \%$, was at its lowest position. This situation showed that the change that happened to management accounting was not yet easy to be used by its users. It probably happened because the change itself was still a new thing and operators needed more time to be accustomed to the use of it.

\section{Conclusion}


The result of the research shows the support to the theory of technology acceptance model which states that one system could be adopted when an individual feel usefulness from that system (Vankatesh and Davis, 2003). It also shows how important is to create particular conditions where sub-units have the capacity to make system changes and capable employees who are willing to assimilate and give responses to new information.

\section{References:}

Abernethy and Lillis. 1995. The impact of manufacturing flexibility on management control system design. Accounting Organization and Society.

Anderson, H. and Young. 2002. Factors Influencing the Performance of activity based costing system teams: a fields study of ABC model development time in the automotive industry, 27, 195-211.

Anderson, S.W. 1995. A Framework for Assessing Cost Management System Changes: The Case of Activity Based Costing Implementation at General Motors, 1986-1993. Journal of Management Accounting Research, 7.

Brevik, E. 2005. User Acceptance of Technology and Success in IS Implementation. Proceeding of the 2005 information Resources Management Association International Conference.

Broadbent and Laughlin. 2005. Organisational and accounting change: theoritical and empirical reflections and thoughts on future research agenda. Journal of Accounting and Organisational Change, 1, 7-26.

Cavalluzzo, K.S. and Ittner, C.D. 2004. Implementing Performance Measurement Innovations: Evidence From Government. Accounting, Organizations and Society, 29, 3-4.

Chenhall, R.H. 2003. Management control systems design within its organizational context: Findings from contingency-based research and directions for the future. Accounting, Organizations and Society, 28, 127-268.

Chenhall, R.H., Langfield-Smith, K. 1998. Adoption and benefits of management accounting practices: An Australian study. Management Accounting Research, 9(1), 1-9.

Campanale, C. 2012. Organizational Changes in Healthcare: a Critical Approach. PhD thesis at Sant'Anna Scuola universitaria superiore pisa, Italy.

Cooper, R. and Turney, P.B. 1989. Hewlett-Packard: the Roseville Network Division, Boston , MA., Harvard Business School, Case No. 9-189-117.

Cooper, R., Kaplan, R.S., Maisel, L.S., Morrissey, E. and Oehm, R.M. 1992. Implementing Activity-Based Cost Management: Moving from Analysis to Action. Institute of Management Accountants.

Davis, F.D., Bagozzi, R.P., Warshaw, P.R. 1989. User Acceptance of Computer-Technology: A Comparison of Two Theoritical Models. Management Science.

Hapsoro, D., Suryanto, T. 2017. Consequences of Going Concern Opinion for Financial Reports of Business Firms and Capital Markets with Auditor Reputation as a Moderation Variable: An Experimental Study. European Research Studies Journal, 20(2A), 197-223.

Innes, J. and Mitchell, F. 1991. ABC: A Survey of CIMA Members. Management Accounting, 69(9).

Jones, G. 2004. Organization Theory, Design and Change. Prentice Hill, International Edition. 
Kaplan, K. 1986. Accounting lag: the obselescence of cost acounting system. California Management review, 28(2), 174-199.

Kotter, J.P. and Schlesinger, L.A. 1979. Choosing strategies for change. Harvard Business Review, 106-114.

Krumwiede, K.R. 1998. The Implementation Stage of Activity Based Costing and the Impact of Contextual and Organizational Factors. Journal of Management Accounting Research, 10.

Lewin, K., Miller, D. 1982. Evolution and Revolution: A Quantum View of structural Change in Organizations. Journal of Management Studies, 19.

Miller, D. 1980. Momentum and Revolution in Organizational Adaptation. Academy of Management Journal, 2.

Permana, D. 2017. Toward the Best Model of Strategy Implementation in Indonesian Islamic Banking from the Lens of Strategic Clarity. European Research Studies Journal, 20(4B), 3-15.

Setyawati, I., Suroso, S., Suryanto, T., Nurjannah, S.D. 2017. Does Financial Performance of Islamic Banking is better? Panel Data Estimation. European Research Studies Journal, 20(2A), 592-606.

Shield, S. 1997. Research in management accounting by North Americans in the 1990s. Journal of Management Accounting Research, 9, 3-61.

Suryanto, T., Thalassinos, I.E. 2017. Cultural Ethics and Consequences in Whistle-Blowing among Professional Accountants: An Empirical Analysis. Journal of Applied Economic Sciences, 6(52), 1725-1731.

Suryanto, T. 2016. Audit Delay and Its Implication for Fraudulent Financial Reporting: A Study of Companies Listed in the Indonesian Stock Exchange. European Research Studies Journal, 19(1), 18-31.

Venkatesh, V., Davis, F.D. 2003. User Acceptaance of information technology: Toward a Unified View. MIS Quarterly, 27(2).

Waweru, Hoque and Uliana. 2004. Management Accounting Change in South Africa. Accounting, Auditing \& Accountability Journal, 17, 675-704. 